\title{
Analysis of the factors determining the yield composing elements of winter wheat in a polyfactorial technological trial set up on chernozem soil
}

\author{
László ZSOMBIK ${ }^{1}$ - Zsuzsa ERDÖS ${ }^{1}$ - Emese SERES ${ }^{2}$ \\ 1: UD IAREF Research Institute of Nyíregyháza H-4400 Nyíregyháza, Westsik Vilmos út 4-6. \\ E-mail: zsombik@agr.unideb.hu; erdoszs@agr.unideb.hu \\ 2: Fitt Agro Kft. H-4700 Mátészalka, Hild János park 2/a. E-mail:seres.emese@gmail.com
}

Keywords: wheat, sowing time, plant density, nitrogen supply, genotype

\section{Introduction}

Sowing time proved to be decisive for the starting time of shooting in the studies of Kiss et al. (2013). Longer growth period had a positive effect on the length of the spike and the number of spikelets, but no correlation was found between the thousand grain weight and the number of grains per spike. Pepó and Kovacevic (2011) found a positive correlation between spring precipitation and wheat yield, and a negative correlation between spring temperature and yield. In the studies of Pepó (2009), the applied NPK fertilization resulted in a yield increase of 2853-3698 $\mathrm{kgha}^{-1}$ in a droughty year. Zsombik and Seres (2018) found that the strongest effect of production year on sour sandy soils appeared in terms of the number of spikes per area unit (78\%), biomass weight (71\%) and yield (69\%). The applied nitrogen increased the value of the Specific Leaf Area (SLA) on sandy soil in proportion to the amount of the applied amount in the scope of the examinations of Simkó et al. (2016). In the studies of Kiss et al. (2018), the change of sowing time and plant density affected spike length, the number of grains per spike, the number of productive shoots, and the weight of grains. The aim of our experiment was to analyse the sowing time and plant density reactions of multiple genotypes with different nitrogen supply levels on chernozem soil, in terms of the most important yield composing elements (spike length, number of grains per spike, grain weight per spike, total spike weight, productive tillering, number of spikes per area unit, biomass weight, Harvest index) and yield in two production years.

\section{Materials and methods}

Our examinations were carried out in the winter wheat production technology trial set up on chernozem soil within the region of Debrecen, in 2015-2016. Our studies involved the extensive winter wheat genotypes $1401 \mathrm{HK}, 1408 \mathrm{HB}$ and the KG Bendegúz winter wheat variety. Agro-technical and plant protection treatments were in conformity with the general practice, in terms of nitrogen supply control, $54 \mathrm{kgha}^{-1}$ and $108 \mathrm{kgha}^{-1}$ treatments were applied in early spring, in the form of MAS $(27 \% \mathrm{~N})$ fertilizer. 3 different sowing dates (October, November, December) and plant density values (2; 3.5 and 5 million per ha) were used. Statistical evaluation of the results was performed by means of the Tukey test and the division of the variance components.

\section{Results and discussion}

Based on the analytical results it can be concluded that the extreme weather conditions of the two years were crucial in terms of the length of the spikes; production year modified the parameter at $46 \%$. Genotype and plant density in determined spike length at $21-21 \%$, sowing time at $11 \%$, while nitrogen supply had only a $1 \%$ influence on chernozem soil. Production year modified the change of spikelet numbers by $37 \%$, genotype by $27 \%$, 
plant density by $25 \%$ sowing time by $7 \%$, while nitrogen resistance at $4 \%$. The change in the number of grains per spike was primarily due to the effect of the genotype (40\%), while stocking density modified the number of grains per spike by $23 \%$, production year and sowing time by $17 \%$ and the nitrogen supply by $3 \%$. The extreme weather conditions of the two analysed years were also significant in terms of the grain weight per spike as well they affected the parameter by $30 \%$, while plant density by $29 \%$, genotype by $28 \%$, sowing time by $8 \%$, and nitrogen supply by $5 \%$. The change in total spike weight was primarily attributable to the effect of the production year $(33 \%)$ and sowing date $(32 \%)$, while genotype changed it by $23 \%$, nitrogen supply by $8 \%$ and stocking density by $4 \%$. The change in Harvest index values is primarily attributable to the effect of the genotype, which contributed by $33 \%$ to the change in the parameter, while production year modified it by $24 \%$, plant density by $19 \%$, sowing time by $15 \%$ and nitrogen supply by $9 \%$. The change in biomass was primarily due to the production year $(44 \%)$, then sowing time $(22 \%)$, genotype $(21 \%)$, nitrogen supply $(8 \%)$ and plant density $(5 \%)$. The change in productive tillering was mainly attributable to the effect of plant density $(47 \%)$, while it was affected by the production year $(23 \%)$, sowing time (14\%), genotype $(13 \%)$ and the role of nitrogen supply (3\%). The change in the number of spikes per area unit was primarily attributable to the effect of the production year (34\%), genotype $(21 \%)$, sowing time and plant density (20-20\%), and nitrogen supply (5\%). Based on the analytical results of the two years, the change in the yield of winter wheat was primarily caused by the change in sowing time (33\%); the effect of the production year was similar $(29 \%)$, while genotype affected it by $17 \%$, plant density by $11 \%$, nitrogen supply by $10 \%$.

\section{Conclusions}

In terms of the analysed parameters, the determinant role of the production year was clear. It mostly affected spike length, the number of spikelets, biomass weight, and number of spikes per area unit. Plant density was significant in terms of productive tillering. Sowing time and total spike weight proved to be significant in terms of the yield, while genotype affected the number of grains per spike and the Harvest-index.

\section{Acknowledgement}

Our research was carried out in the scope of the AGR_PIAC_13-1-2013-0002 project, "Production of adaptive winter wheat lines with excellent milling parameters".

\section{References}

Kiss, T., Balla, K., Bányai, J., Veisz, O., Karsai, I. (2013): Effect of different sowing times on the plant developmental parameters of wheat (Triticum aestivum L.). Cereal Research Communications. 42: 2. 239-251. https://doi. org $/ 10.1556 /$ crc. 2013.0064

Kiss, T., Balla, K., Bányai, J., Veisz, O., Karsai, I. (2018): Associations between plant density and yield components using different sowing times in wheat (Triticum aestivum L.). Cereal Research Communications, 46: 2. 211-220. https://doi.org/10.1556/0806.45.2017.069

Pepó, P., Kovacevic, V. (2011): Regional analysis of winter wheat yields under different ecological conditions in Hungary and Croatia. Acta Agronomica Hungarica 59. 1. 23-33. https://doi.org/10.1556/aagr.59.2011.1.3

Pepó, P. (2009): Eltérő évjárattípusok és agrotechnikai tényezők interaktív hatása az őszi búza (Triticum aestivum L.) termésére. Növénytermelés. 58: 2. 53-66. https://doi.org/10.1556/novenyterm.58.2009.2.7

Simkó A., Kiss L., Zsombik L., Veres Sz. (2016): Csökkentett nitrogén ellátás hatása búza genotípusok fotoszintetikus válaszreakcióira. LVIII. Georgikon Napok. Keszthely: PE Georgikon Kar. 327-333.

Zsombik L., Seres E. (2018): Nitrogénkezelések őszi búza (Triticum aestivum L.) agronómiai paramétereire gyakorolt hatása savanyú homoktalajon. Növénytermelés. 67: 2. 87-108.

doi: 10.34116/NTI.2019.AA.79 